\title{
Herbal Remedies Role in Improving Cows' Milk Safety and Quality
}

\author{
G. A. Larionov, O. Yu. Checheneshkina, R.N. \\ Ivanova, M.G. Terentyeva \\ Department of biotechnology and processing of agricultural \\ products \\ Chuvash State Agricultural Academy \\ Cheboksary, Russia \\ larionovga@mail.ru
}

\author{
Alekseev V.A. \\ Department of General and Particular Zootechnics \\ Chuvash State Agricultural Academy \\ Cheboksary, Russia \\ larionovga@mail.ru
}

\begin{abstract}
Production of safe and high-quality milk with the disease of cows with mastitis is the relevant objective. In the production of milk, it is necessary to strictly observe the technology and the veterinary and sanitary rules for milking, to carry out timely diagnosis and treatment of cows with subclinical mastitis. An analysis of the causes of lesions in the quarters of the mammary gland was carried out in the conditions of the Chuvash Republic and the main directions for timely diagnosis and prevention of subclinical mastitis of cows were established. The dynamics of damage to quarters of an udder with mastitis during the lactation period was determined and the combined use of herbal preparations with a positive effect was tested - pihtoin ointment and gel trauma for the treatment of subclinical mastitis of cows, which ensures safety and high quality products. It has been established that the use of pihtoin ointment in the treatment of cows with subclinical mastitis reduces the microbial contamination of milk 1.56 times, and the use of trauma-gel preparation - 1.15 times. The trauma-gel drug helps reduce the number of somatic cells in milk.
\end{abstract}

Keywords-udder, mastitis, trauma-gel, pihtoin ointment.

\section{INTRODUCTION}

Dairy farming is the leading direction in the structure of the entire agro-industrial complex. Getting quality and safe milk from cows is an urgent task for milk producers. One of the reasons for the poor quality of milk is disease of cows with mastitis. The high content of somatic cells in milk reduces heat resistance and other technological properties of milk. Milk obtained from cows with mastitis causes staphylococcal infections in humans. Diagnosis of latent mastitis is of great importance both in the period of lactation and in the dry period [1-17].

The aim of the research is to develop and conduct veterinary and sanitary measures for the prevention and treatment of subclinical mastitis in cows during the lactation period.

The following tasks were set to achieve the goal:

To conduct a veterinary and sanitary examination of cows' milk. To determine the factors affecting the content of microorganisms and somatic cells in the milk of cows and to take measures to reduce them.

To establish the dynamics of lesions of the udder of cows with subclinical mastitis.

To analyze the effectiveness of the use of plant preparations - pihtoin ointment and trauma-gel preparation and to justify their combined use for the treatment of cows with subclinical mastitis.

\section{METHODS}

The experimental work was carried out on the basis of the Accredited Test Laboratory of the budget institution of the Chuvash Republic "Chuvash Republican Veterinary Laboratory" of the State Veterinary Service of the Chuvash Republic.

Research work was carried out on the base of a commercial dairy farm of the integrated agricultural production centre-collective farm named after Lenin, Cheboksary district of the Chuvash Republic (CR).

3 experimental groups and 1 control group of Holstein black-and-white cows were formed for the research according to the analogue group method, taking into account body weight and age of animals. The quality of cow's milk was homogeneous in terms of physico-chemical parameters. During the study period, cows of all groups were fed on the same type of ration under the conditions of the same management, feeding and milking conditions.

The study of the dynamics of udder damage and the effects of herbal-based drugs on the effectiveness of the treatment of subclinical mastitis and the quality of cows' milk was performed in a commercial dairy farm number 1 (CDF 1) with a population of 180 milk cows. The way of keeping cows is tie-up housing, using pasture in summer. During the stall period, cows are kept on a leash in a room; for exercise, paddocks are used for the exercise of cows. The farm is equipped with the ADM-8 milking machine with a milk line. Milking of cows is carried out in stalls in glass milk lines. The studies included a research of the quality of milk in terms of 
organoleptic and physicochemical parameters; analysis of milk from each quarter of the udder for subclinical mastitis using the California test and kenotest, clinical examination of cows with a high content of somatic cells in milk.

A study of the quality of milk in the dairy laboratory of the farm for organoleptic and physico-chemical properties was conducted in the preparatory period. The number of somatic cells in milk, the bacterial contamination of milk, the presence of abnormal milk, antibiotics, and inhibiting substances were determined in the republican veterinary laboratory. An increased content of somatic cells was revealed in the milk of cows MTF 1 . The results of milk quality research in the initial period were taken as the initial ones.

In the main period, cows' milk was examined for subclinical mastitis with the help of quick mastitis tests. The frequency of lesions in quarters of the cows udder during subclinical mastitis in the period of lactation was determined and the causes of the disease were revealed.

In the final period, cows were treated with plant-based preparations - pihtoin ointment and trauma-gel preparation, and their effectiveness in treating subclinical mastitis was determined (Table 1).

TABLE I. ADMINISTRATION OF HERBAL PRODUCTS

\begin{tabular}{|c|c|c|c|c|}
\hline \multirow[b]{2}{*}{ Indicator } & \multicolumn{4}{|c|}{ Group } \\
\hline & $\begin{array}{c}1 \\
\text { experime } \\
\text { ntal }\end{array}$ & $\begin{array}{c}2 \\
\text { experime } \\
\text { ntal }\end{array}$ & $\begin{array}{c}3 \\
\text { experime } \\
\text { ntal }\end{array}$ & 4 control \\
\hline $\begin{array}{l}\text { Number of cows, } \\
\text { heads }\end{array}$ & 45 & 45 & 45 & 45 \\
\hline $\begin{array}{l}\text { Number of cows, } \\
\text { heads: } \\
\text { - with subclinical } \\
\text { mastitis; } \\
\text { - recovered }\end{array}$ & $\begin{array}{c}18 \\
3\end{array}$ & $\begin{array}{l}19 \\
12\end{array}$ & $\begin{array}{l}14 \\
14\end{array}$ & $\begin{array}{l}7 \\
4\end{array}$ \\
\hline Preparation & $\begin{array}{l}\text { Pihtoin } \\
\text { ointment }\end{array}$ & $\begin{array}{l}\text { Drug } \\
\text { trauma } \\
\text { gel }\end{array}$ & $\begin{array}{l}\text { Pihtoin } \\
\text { ointment } \\
\text { and } \\
\text { trauma } \\
\text { gel }\end{array}$ & $\begin{array}{l}\text { Mastitis } \\
\text { Forte }\end{array}$ \\
\hline $\begin{array}{l}\text { Multiplicity of } \\
\text { treatment }\end{array}$ & \multicolumn{3}{|c|}{$\begin{array}{c}2 \text { times a day with an interval of } 12 \\
\text { hours }\end{array}$} & $\begin{array}{l}\text { Once a day } \\
\text { at a dose of } \\
10 \mathrm{ml}\end{array}$ \\
\hline Treatment modality & \multicolumn{3}{|c|}{$\begin{array}{c}\text { application } \\
\text { affected udder quarter }\end{array}$} & $\begin{array}{l}\text { intracistern } \\
\text { ally }\end{array}$ \\
\hline $\begin{array}{l}\text { Duration of treatment, } \\
\text { day }\end{array}$ & \multicolumn{4}{|c|}{5} \\
\hline
\end{tabular}

Studies were performed using zoohygienic methods: The temperature, humidity, air velocity, carbon dioxide, ammonia and hydrogen sulfide content in the air, microbial contamination and dust content in the room air were determined on the commercial dairy farm. Clinical and physiological methods were used to determine body temperature, pulse rate and respiration in animals of the control and experimental groups. Veterinary-sanitary examination of milk was performed by the following methods: organoleptic - determined color, smell, taste and texture; areometric method - density; titration - acidity; filtering - the purity group; Gerber's acid method - a mass fraction of fat; measuring the mass fraction of total nitrogen according to
Kjeldahl - the mass fraction of protein; by the arbitration method - the mass fraction of dry matter and dry skimmed milk residue; method of counting colonies of mesophilic aerobic and facultative anaerobic microorganisms QMAFAnM (Quantity of Mesophilic Aerobic and Facultative Anaerobic Microorganisms); with the use of methylene blue indicator - inhibiting substances; by identifying bacteria of the genus Salmonella - pathogens, incl. salmonella; by changing the viscosity in a visual way and using a viscometer - the number of somatic cells.

Statistical processing was performed by the method of variation statistics on the reliability of the differences of compared indicators. The values of arithmetic means (M), standard deviations ( $\%$ ), average errors $(\mathrm{m})$ calculated by using Microsoft Office Excel 2007 software program. The degree of reliability of differences in average values in cases of normal distribution was determined using Student's criterion.

\section{RESULTS}

Milk production is carried out on two farms in the integrated agricultural production centre named after Lenin of the Cheboksary District. Commercial dairy farm 1 applies tethered one, Commercial dairy farm 2 applies loose keeping of cows. The quality of milk differs depending on the method of keeping cows. Mass fraction of protein and fat in milk within the basic norms. Acidity, purity group, density of milk meet the requirements.

The content of microorganisms and somatic cells in milk significantly exceeds the requirements, which makes it necessary to identify the causes, develop and conduct measures to eliminate them.

In this regard, production experiments to determine the safety and quality of milk were carried out in the conditions of the integrated agricultural production centre named after Lenin. Veterinary and sanitary measures to reduce the content of microorganisms and somatic cells in the milk of cows were developed and carried out.

Milk of cows, like other types of agricultural products, is primarily determined by safety. These requirements are reflected in the regulatory and technical documents applied in the Russian Federation (RF): GOST R 52054-2003 "Cow's milk raw. Technical conditions"; Technical Regulations of the Customs Union "On the safety of milk and dairy products" (TR CU 033/2013).

At the beginning of the research in the spring-summer period, the number of mesophilic aerobic and optional anaerobic microorganisms (QMAFAnM) was 390-497 in the milk of cows of Commercial dairy farm 1 and 340-413 thousand of Commercial dairy farm $2 \mathrm{CFU} / \mathrm{cm}^{3}$. On average, QMAFAnM in milk of cows of CDF 1 was 440, CDF 2 - 370 thousand CFU $/ \mathrm{cm}^{3}$ at a rate for milk not more than 500 thousand $\mathrm{CFU} / \mathrm{cm}^{3}$ according to the requirements of TR CU $033 / 2013$.

The number of somatic cells (SC) in the milk of cows of CDF 1 averaged 600 thousand $/ \mathrm{cm}^{3}$ with an oscillation interval of $430-1000$ thousand $/ \mathrm{cm}^{3}$, while the norm for milk is not 
more than 750 thousand $/ \mathrm{cm}^{3}$ according to the requirements of TR CU 033/2013.

The number of somatic cells in the milk of cows of CDF 2 was significantly lower and averaged 500 thousand $/ \mathrm{cm}^{3}$, the interval was $310-580$ thousand $/ \mathrm{cm}^{3}$.

Thus, it was established that on the average bacterial contamination and the number of somatic cells in cow's milk meets the requirements of TR CU 033/2013. According to the requirements of GOST R 52054-2003 "Cow's milk raw. Technical conditions", milk of cows of CDF integrated agricultural production centre named after Lenin, and by QMAFAnM, and SC corresponds only to the second grade.

In this regard, the implementation of sanitary and hygienic measures, aimed at reducing bacterial contamination and the number of somatic cells in the milk of cows, is relevant.

The results of our researches confirm that an important factor in preserving the quality of milk is proper organization of the hygiene of cows milking and compliance with instructions for using milking equipment.

To reduce the overall bacterial contamination of milk, the number of somatic cells and improve its quality and safety on the dairy farms, the agricultural collective farm named after Lenin together with the specialists of the farm developed and carried out sanitary and hygienic measures: bacteriological studies of udder secretion of mastitis cows; identifying the source of the disease; timely implementation of preventive and therapeutic measures; monitoring compliance with the rules of milking; identification and treatment of cows with reproductive organs; regular monitoring of the state of the mammary gland of cows; control of the level of somatic cells in milk with rapid mastitis tests to detect latent mastitis.

The implementation of sanitary and hygienic measures led to the fact that the bacterial contamination of milk in the spring-summer period of the second year of research as compared with the first year of the same period by CDF 1 decreased 1.8 times and amounted to 73-373 thousand $\mathrm{CFU} / \mathrm{cm}^{3}$. With CDF 2, QMAFAnM decreased 4.6 times with an interval of oscillations of 59-117 thousand. $\mathrm{CFU} / \mathrm{cm}^{3}$. The average content of QMAFAnM in the milk of cows of CDF 1 and CDF 2 was 250 and 80 thousand, respectively, $\mathrm{CFU} / \mathrm{cm}^{3}$. According to the requirements of GOST R 52054-2003, the quality of milk corresponds to the first and the highest grade, respectively (Table 2).

Veterinary and sanitary measures carried out in the first and second years of research at CDF 1 made it possible to reduce $\mathrm{SC}$ in milk from 600 to 500 thousand $/ \mathrm{cm}^{3}$, on CDF 2 from 500 to 400 thousand $/ \mathrm{cm}^{3}$, which meets the requirements of the technical regulations of the Customs Union "On safety milk and dairy products" (TR CU 033/2013). However, in accordance with the requirements of GOST R 52054-2003, milk does not meet the requirements of the highest grade.

A high concentration of microorganisms and somatic cells in the milk of cows, in our opinion, is a sign of impaired udder secretion or disease of cows.
TABle II. The EFFect Of SANitARy-Hygienic MeAsures On The Content Of Microorganisms And Somatic Cells In The Milk Of Cows

\begin{tabular}{|c|c|c|c|c|c|}
\hline \multirow{3}{*}{ Indicator } & \multirow{3}{*}{$\begin{array}{c}\text { Standard } \\
\text { for milk } \\
\text { according } \\
\text { to TR CU } \\
033 / 2013\end{array}$} & \multicolumn{4}{|c|}{ The result of research } \\
\hline & & \multicolumn{2}{|c|}{ the first year } & \multicolumn{2}{|c|}{ the second year } \\
\hline & & CDF 1 & CDF 2 & CDF 1 & CDF 2 \\
\hline $\begin{array}{l}\text { QMAFAnM, } \\
\text { CFU/cm3 (g), } \\
\text { not more }\end{array}$ & $5,0 \times 10^{5}$ & $3,4 \times 10^{5}$ & $3,7 \times 10^{5}$ & $2,5 \times 10^{5}$ & $0,8 \times 10^{5}$ \\
\hline $\begin{array}{l}\text { Requirements } \\
\text { GOST R 52054- } \\
2003\end{array}$ & & & & & \\
\hline highest grade & $1,0 \times 10^{5}$ & & & & + \\
\hline first quality & $3,0 \times 10^{5}$ & & & + & \\
\hline second quality & $5,0 \times 10^{5}$ & + & + & & \\
\hline $\begin{array}{l}\text { Somatic cells } \\
\text { in } 1 \mathrm{~cm}^{3} \text {, not } \\
\text { more }\end{array}$ & $7,5 \times 10^{5}$ & $6 \times 10^{5}$ & $5 \times 10^{5}$ & $5 \times 10^{5}$ & $4 \times 10^{5}$ \\
\hline $\begin{array}{l}\text { Requirements } \\
\text { GOST R 52054- } \\
2003\end{array}$ & & & & & \\
\hline highest grade & $2,5 \times 10^{5}$ & & & & \\
\hline first quality & $4,0 \times 10^{5}$ & & & & + \\
\hline second quality & $7,5 \times 10^{5}$ & + & + & + & \\
\hline
\end{tabular}

Maintaining udder health in cows is especially important during the lactation period, when the mammary gland of a cow is under tremendous stress. Mastitis of cows causes significant damage to the farm from premature cows' disposal, reduced performance of dairy cows, the morbidity of calves, the cost of diagnosis, treatment, etc. It is an important task of farm specialists to recognize the disease in time and to prevent its spread.

The distribution of subclinical mastitis of cows during lactation was studied to successfully solve the problem of increasing the number of somatic cells in milk. Studies of a quarter of the udder of cows for mastitis were performed on CDF 1 within two years during lactation. California mastitis test and kenotest were used to determine the number of somatic cells in the secretion of the udder. Milk with a positive reaction was tested by settling test (Table 3 ).

It was established that subclinical mastitis of cows during lactation often develops in spring and summer. So in November, subclinical mastitis was found in 30 cows, which is $16 \%$ of the herd, in July - in 58 cows or $32 \%$.

The use of pihtoin ointment in the treatment of cows with subclinical mastitis led to recovery of the udder of $16.7 \%$ of cows. The number of mesophilic aerobic and optionally anaerobic microorganisms in the milk of the first experimental group decreased 1.6 times. The number of somatic cells with the use of pihtoin ointment in the experimental group did not change and amounted to 420 thousand in $1 \mathrm{~cm}^{3}$ of milk, while the demand for top grade milk was not more than 250 thousand in $1 \mathrm{~cm}^{3}$. 
TABLE III. UDDER LESION BY INFLAMMATORY PROCESS IN CASE OF SUBCLINICAL MASTITIS OF COWS DURING LACTATION

\begin{tabular}{|c|c|c|c|c|c|c|c|c|}
\hline \multirow{4}{*}{$\begin{array}{l}\text { Udder } \\
\text { shares }\end{array}$} & \multicolumn{8}{|c|}{ Group } \\
\hline & \multicolumn{2}{|c|}{$\begin{array}{c}1 \\
\text { experimental }\end{array}$} & \multicolumn{2}{|c|}{$\begin{array}{c}2 \\
\text { experiment } \\
\text { al }\end{array}$} & \multicolumn{2}{|c|}{$\begin{array}{c}3 \\
\text { experiment } \\
\text { al }\end{array}$} & \multicolumn{2}{|c|}{4 control } \\
\hline & \multicolumn{8}{|c|}{ Year of study } \\
\hline & First & $\begin{array}{c}\text { Seco } \\
\text { nd }\end{array}$ & $\begin{array}{c}\text { Fir } \\
\text { st }\end{array}$ & $\begin{array}{c}\text { Seco } \\
\text { nd }\end{array}$ & $\begin{array}{l}\mathbf{F i} \\
\text { rst }\end{array}$ & $\begin{array}{c}\text { Seco } \\
\text { nd }\end{array}$ & First & $\begin{array}{c}\text { Seco } \\
\text { nd }\end{array}$ \\
\hline $\begin{array}{l}1 \text { quarter, } \\
\%\end{array}$ & 63.6 & 72.2 & $\begin{array}{c}69 . \\
6\end{array}$ & 57.9 & $\begin{array}{c}10 \\
0\end{array}$ & 64.3 & 60.0 & 28.6 \\
\hline $\begin{array}{l}2 \text { quarter, } \\
\%\end{array}$ & 36.4 & 22.2 & $\begin{array}{c}30 . \\
4\end{array}$ & 36.8 & - & 37.7 & 40.0 & 71.4 \\
\hline $\begin{array}{l}3 \text { quarter, } \\
\%\end{array}$ & - & - & - & 5.3 & - & - & - & - \\
\hline $\begin{array}{l}4 \text { quarter, } \\
\%\end{array}$ & - & 5.6 & - & - & - & - & - & - \\
\hline $\begin{array}{l}\text { Diseased } \\
\text { cows, } \\
\text { heads }\end{array}$ & 11 & 18 & 23 & 19 & 1 & 14 & 10 & 7 \\
\hline $\begin{array}{l}\text { Diseased } \\
\text { cows, } \%\end{array}$ & 24.4 & 40.0 & $\begin{array}{c}51 . \\
1\end{array}$ & 42.2 & 2.2 & 31.1 & 22.2 & 15.6 \\
\hline
\end{tabular}

Thus, the milk of cows in the control and experimental groups according to the content of microorganisms and somatic cells corresponds to the first grade.

The use of the trauma-gel preparation in the treatment of subclinical mastitis of cows in the second experimental group resulted in recovery of the udder of $63.2 \%$ of sick cows. The content of microorganisms in milk decreased by $13 \%$. At the same time, QMAFAnM amounted to 410 thousand. CFU/ $\mathrm{cm}^{3}$. The number of somatic cells in the milk of cows in the experimental group decreased $2.4 \%$ and amounted to 400 thousand in $1 \mathrm{~cm}^{3}$, which corresponds to the requirements of TR CU 033/2013.

The effect of the combined use of pihtoin ointment and trauma-gel drug on the quality of milk of cows was studied in the third experimental group. All 14 sick cows recovered, which was $100 \%$ with the combined treatment of subclinical mastitis. It was found that QMAFAnM decreased 2.6 times and amounted to 180 thousand $\mathrm{CFU} / \mathrm{cm}^{3}$, at a rate of 100 thousand $\mathrm{CFU} / \mathrm{cm}^{3}$ for top grade milk. The number of somatic cells in the milk of the third experimental group decreased 1.3 times and amounted to 320 thousand in $1 \mathrm{~cm}^{3}$. A significant decrease in the number of somatic cells in cow's milk with a combined treatment led to an improvement in the quality of milk.

From our point of view, this is due to the fact that the trauma-gel preparation has a hydrophilic base penetrating deep into the tissues, such base makes it possible to apply it even on fresh wounds. Trauma-gel quickly restores tissue immunity in the injury hotspots, blocks the development of pathogenic microflora, stimulates wound self-cleaning and the development of granulation tissue.

In our studies, the trauma-gel preparation was applied to the damaged or painful places after the pre-trimming with a thin layer 2 times a day, easily rubbing into the skin. At the same time, a decrease in the number of somatic cells by $2.5 \%$ was established. The combined use of pihtoin ointment and trauma-gel preparation for the treatment of cows allowed reducing the number of somatic cells and improving the quality of milk (Table 4).

TABle IV. EFFect Of Pihtoin Ointment And Trauma-Gel Preparation On The Content Of Microorganisms AND Somatic Cells In The MiLK OF COWS

\begin{tabular}{|c|c|c|c|c|c|}
\hline \multirow[b]{2}{*}{ Indicator } & \multirow{2}{*}{$\begin{array}{c}\text { Standard } \\
\text { for milk } \\
\text { according } \\
\text { to TR CU } \\
033 / 2013\end{array}$} & \multicolumn{4}{|c|}{ Group } \\
\hline & & $\begin{array}{c}1 \\
\text { experime } \\
\text { ntal }\end{array}$ & $\begin{array}{c}2 \\
\text { experime } \\
\text { ntal }\end{array}$ & $\begin{array}{c}3 \\
\text { experime } \\
\text { ntal }\end{array}$ & $\begin{array}{c}4 \\
\text { control }\end{array}$ \\
\hline $\begin{array}{l}\text { QMAFAnM } \\
\text { CFU / } \mathrm{cm}^{3} \\
\text { (g), not more } \\
\text { than }\end{array}$ & $5,0 \times 10^{5}$ & $3,0 \times 10^{5}$ & $4,1 \times 10^{5}$ & $1,8 \times 10^{5}$ & $4,7 \times 10^{5}$ \\
\hline $\begin{array}{l}\text { Requirement } \\
\text { s GOST R } \\
52054-2003\end{array}$ & & & & & \\
\hline highest grade & $1,0 \times 10^{5}$ & & & & \\
\hline first quality & $3,0 \times 10^{5}$ & + & & + & \\
\hline $\begin{array}{l}\text { second } \\
\text { quality }\end{array}$ & $5,0 \times 10^{5}$ & & + & & + \\
\hline $\begin{array}{l}\text { Somatic cells } \\
\text { in } 1 \mathrm{~cm} 3(\mathrm{~g}) \text {, } \\
\text { not more }\end{array}$ & $7,5 \times 10^{5}$ & $4,2 \times 10^{5}$ & $4,0 \times 10^{5}$ & $3,2 \times 10^{5}$ & $4,1 \times 10^{5}$ \\
\hline $\begin{array}{l}\text { Requirement } \\
\text { s GOST R } \\
52054-2003\end{array}$ & & & & & \\
\hline highest grade & $2,5 \times 10^{5}$ & & & & \\
\hline first quality & $4,0 \times 10^{5}$ & & + & + & \\
\hline $\begin{array}{l}\text { second } \\
\text { quality }\end{array}$ & $7,5 \times 10^{5}$ & + & & & + \\
\hline
\end{tabular}

Timely diagnosis of subclinical mastitis, reliable prevention, effective treatment form the basis of measures to combat mastitis and contribute to improving the quality of milk.

The quality control of cows' milk using the Californian test and kenotest allowed revealing subclinical mastitis and timely treatment.

It was revealed that QMAFANM in the milk of cows of the experimental and control groups ranges from 180 thousand to 470 thousand, while the norm is not more than 100 thousand $\mathrm{CFU} / \mathrm{cm}^{3}$ for top grade milk. SC in the milk of cows of 1 experimental group was 420 thousand in $1 \mathrm{~cm}^{3}(\mathrm{P} \leq 0.05)$, 2 experimental group - 400 thousand $(\mathrm{P} \leq 0.05), 3$ experimental group - 320 thousand $(\mathrm{P} \leq 0.05)$, the control group - 410 thousand in $1 \mathrm{~cm}^{3}$.

Thus, the quality of the milk of cows from the experimental and control groups according to QMAFAnM and SC conforms to the requirements of TR CU 033/2013. According to GOST R 52054-2003, milk meets the requirements of the first and second grade. 


\section{DISCUSSION}

Milk on the specifics of its receipt always contains a certain number of bacteria. The higher the quality, the lower the content of bacteria and mechanical impurities. The number of mesophilic aerobic and optional anaerobic microorganisms in accordance with the requirements of the technical regulations of the Customs Union "On the safety of milk and dairy products" (TR CU 033/2013) in cow's milk is allowed not more than $5 \times 10^{5} \mathrm{CFU} / \mathrm{cm}^{3}$, the number of somatic cells is not more than $7,5 \times 10^{5}$ in $1 \mathrm{~cm}^{3}$. Requirements of GOST R 52054-2003 "Raw cow milk. Technical conditions" to the quality of milk on QMAFAnM and SC are much higher.

According to the norms of European standards, no more than $2.5 \times 10^{5}$ somatic cells per $1 \mathrm{~cm}^{3}$ are allowed in milk. In the USA, a herd of cows is considered prosperous due to mastitis if somatic cells in milk are not more than $2 \times 10^{5}$ per $1 \mathrm{~cm}^{3}$

Various factors contribute to the appearance of mastitis in the herd. First of all, bacteria are present in the environment of the cow, and especially there are a lot of them on the litter. Mastitis caused by the environment, appears mainly as a result of poor-quality, dirty litters for animals, which was revealed at the initial stage of our research. Udder invasion occurs between milkings. Cows are particularly susceptible to these bacteria at the beginning of their "dry" period, when the dug channels are opened [1-17].

Mastitis in cows is observed in any period of lactation, while high-yielding animals often get sick, which leads to significant losses. It is necessary to identify all the factors that contribute to the emergence and spread of the disease to increase the effectiveness of the developed measures for the prevention of subclinical mastitis of cows during lactation. Our researches confirm the results of scientists about the need to organize the timely detection of the initial stages of inflammation of the mammary gland of cows with regular testing of milk and carrying out the necessary treatment [7-8]

The criterion for the intensity of the incidence of cows with mastitis and the presence of impurities of mastitis milk is the number of somatic cells. However, it should be remembered that this indicator in healthy cows may increase immediately after calving, before starting, during estrum, as well as in old animals that had previously suffered from mastitis.

Somatic cells are the usual components of normal milk, they are represented by leukocytes and epithelium of the alveoli and the lactating ducts. The secretion of healthy cows is dominated by epithelial cells formed during natural aging and tissue renewal. With mastitis, leukocyte migration increases to the inflammation site, which leads to a sharp increase in the number of somatic cells. According to research, $1 \mathrm{ml}$ of milk of healthy cows of all ages contains an average of 250 thousand somatic cells, and with the disease subclinical mastitis this value is almost four times more. Counting somatic cells in raw milk, as well as counting bacterial contamination, are common methods for assessing the quality of milk in all countries producing milk and dairy products. These indicators are used not only as criteria for payment to milk producers, but also they are a means of assessing the state of the udder of the cow [1-17].

As shown by the results of our research, of other scientists and practitioners, the main factor affecting the number of somatic cells is an infection of the udder in the past or present. Other factors, such as lactation period, age and seasonality, are considered less significant.

Clinical and subclinical forms of inflammation lead to a significant loss of productivity not only in the current, but also in subsequent lactation. This is due to the death of part of the cells of the secretory epithelium of the mammary gland and regeneration due to connective tissue. In some cases, we observed atrophy of individual quarters of the udder.

Monitoring of the herd to identify the clinical and subclinical forms of mastitis in our research has made it possible to effectively use a wide range of measures [8-9]. Prevention of mastitis on the farm should consist of a complex of veterinary and sanitary, zoohygienic, zootechnical and economic and organizational measures. Untimely detection, late or irrational treatment of mastitis causes atrophy of the affected udder. As a result, the cow becomes dairy-free and economically unsuitable. It is necessary to apply full feeding, active exercise, comply with the requirements for sanitary conditions and microclimate of the premises, follow the rules for milking cows, carry out timely diagnostic tests for mastitis and treatment to prevent mastitis in cows. It is necessary to organize the diagnosis of mastitis of cows on the farm during the interlactation period twice, checking the cows 10-15 days from the beginning of the dry period and 10-15 days before calving and carrying out the necessary treatment of the udder with drugs used in the dry period.

Our research confirms that cows are susceptible to new infections within 10 days before and 10 days after calving, due to the fact that the concentration of antibiotics decreases, the teat canals are usually opened, the cow lies a lot, and immunological mechanisms change in animals. The most common environmental microorganisms are Esherichia coli and Streptococcus uberis.

Research by many scientists confirms that mastitis can be forgotten if all aspects relating to the cow's environment and milking procedures are carefully observed because this reduces the number of bacterial populations on the udder and dugs surfaces, especially at the tips of the dugs.

The integrated agricultural production centre named after Lenin revealed two main forms of mastitis - clinical and subclinical. Clinical mastitis - with visible signs of illness. With this form of mastitis, cows had udder edema, high fever, redness, pain, and a change in secretion. Clinical mastitis caused a decrease in milk production. An organoleptic evaluation revealed the presence of flakes and clots in the milk, the watery color of the milk. Subclinical mastitis was determined using special tests. It was revealed that the infected part of the udder of the animal looks normal, the milk is outwardly unchanged, but milk yield and milk quality are reduced.

In the work carried out under the conditions of integrated agricultural production centre named after Lenin, cows were 
examined for subclinical mastitis. The frequency of lesions of quarters of the udder and the causes of disease of cows were determined during lactation. The effectiveness of plant-based drugs for subclinical mastitis was studied. According to the research, measures have been developed to improve the quality of milk based on the prevention of subclinical mastitis. Herbal preparations used in the studies - pihtoin ointment and trauma-gel. These products were used to treat cows, alternating every other day: Pihtoin ointment - in 1, 3, 5 days, trauma-gel - in 2 and 4 days. The multiplicity and application 2 times a day with an interval of 12 hours during five days by applying the drug on the skin of the affected quarter of the udder after washing with clean water, drying and predistributing milk from the sick quarter.

The conducted research allowed conducting an early diagnosis of subclinical mastitis and prescribing appropriate treatment, reducing damage from milk loss, preventing culling of the animal, and preserving the quality of milk.

The degree of decline in the productivity of cows due to mastitis depends on the stage of the disease and varies from subtle changes to the complete cessation of milk secretion. Technological parameters of milk of cows with mastitis are reduced due to: increase in the amount of chlorine and sodium; reducing the content of low-fat solids; reducing the ability of milk proteins to coagulate (inertness of rennet, delayed secretion of whey); appearance of inhibitors in milk as a result of therapeutic interventions.

The results of our research confirm that the incidence can be determined by the number of somatic cells in one-quarter milk. Quarters, in the milk of which the number of somatic cells averages up to 100 thousand per $1 \mathrm{ml}$, are considered healthy. As practice shows, this indicator may vary from 50 thousand to 200 thousand in $1 \mathrm{ml}$ depending on, for example, the age of the cow, feeding and conditions in the barn. The presence of somatic cells in $1 \mathrm{ml}$ of milk in an amount of from 300 thousand to 800 thousand indicates subclinical mastitis. On average, about $5-35 \%$ of quarters of the udder of the entire herd are infected with pathogenic bacteria, i.e. have signs of subclinical mastitis.

Various drugs are used in the treatment of mastitis. We used herbal based products in our research. The use of pihtoin ointment in the treatment of subclinical mastitis led to a decrease in QMAFAnM in the milk of cows 1.6 times. The number of somatic cells when using pihtoin ointment in the experimental group did not change and amounted to 420 thousand in $1 \mathrm{~cm}^{3}$ of milk.

The use of the trauma-gel preparation in the treatment of subclinical mastitis in cows led to a decrease in the content of microorganisms by $13 \%$. At the same time, QMAFAnM amounted to 410 thousand. $\mathrm{CFU} / \mathrm{cm}^{3}$. The number of somatic cells in the cow's milk of the experimental groups decreased by $2.4 \%$ and amounted to 400 thousand in $1 \mathrm{~cm}^{3}$.

The combined application of pihtoin ointment and traumagel preparation in the treatment of subclinical mastitis of cows reduced QMAFAnM 2.6 times. The number of somatic cells in milk decreased in 1.3 times. The use of the combined treatment of animals of the third experimental group contributed to a significant decrease in SC in the cow's milk.

When comparing the damage caused by mastitis and the cost of measures to eliminate it, it was established that the amount of damage is several times higher than the costs necessary for a successful struggle with clinical mastitis of cows.

The economic damage from mastitis consists of the following factors:

- in cows that have gone through mastitis, milk production decreases to $300 \mathrm{~kg}$ from 1 cow per year;

- irreversible changes in breast tissue occur (proliferation of connective tissue) and the previous milk yield is not restored

- animals of high value for breeding and productive attitude are prematurely rejected due to the atrophy of udder quarters;

- the incidence of calves and their mortality is increased.

The use of milk with a high content of somatic cells reduces the quality of dairy products made from it (butter, cheese, sour cream, kefir). The possibility of expanding the range of products, which in turn leads to a decrease in the purchase price for milk from milk processing enterprises, is also decreasing.

In addition to the economic damage, mastitis is a direct source of contamination of milk with microbes, their metabolic products and toxins, which cause various intestinal and respiratory infections in people, especially in children, i.e. the milk safety indicator is reduced.

Thus, with the combined application of pihtoin ointment and the trauma-gel preparation, the cost of treating one cow is reduced 3.8 times. There is no damage from the rejection of milk, which is available during treatment with antibiotics.

\section{CONCLUSION}

The veterinary-sanitary examination found that the milk of cows of the integrated agricultural production centre named after Lenin complies with the requirements of the Technical Regulations of the Customs Union "On the safety of milk and dairy products" (TR CU 033 / 2013) by the mass fraction of protein and fat, acidity and density, bacterial contamination and the number of somatic cells. Requirements of GOST R 52054-2003 "Raw cow milk. Technical conditions" are not met for bacterial contamination and the number of somatic cells.

It was found that subclinical mastitis in cows develops when the rules for milking are violated during lactation. Measures taken to eliminate violations of the rules for milking cows allowed one to reduce the bacterial contamination of the milk of CDF 1 cows 1.8 times, CDF $2-4.6$ times. The number of mesophilic aerobic and optional anaerobic microorganisms in the milk of cows of CDF 1 and CDF 2 averaged 250 and 80 thousand $\mathrm{CFU} / \mathrm{cm}^{3}$, respectively. 
The number of somatic cells in the milk of cows of CDF 1 and CDF 2 decreased by 100 thousand $/ \mathrm{cm}^{3}$ and amounted to 500 and 400 thousand $/ \mathrm{cm}^{3}$, respectively.

Veterinary and sanitary measures at CDF 2 contributed to improving the quality of milk.

It was established that subclinical mastitis in cows during lactation often develops in spring and summer and is 16 and $32 \%$, respectively.

The use of pihtoin ointment in the treatment of cows with subclinical mastitis led to a decrease in the number of mesophilic aerobic and facultative anaerobic microorganisms in milk 1.56 times, and the use of trauma-gel preparation 1.15 times.

Trauma-gel preparation helped to reduce the number of somatic cells in milk to 400 thousand in $1 \mathrm{~cm}^{3}$.

\section{SUMMARY}

The combined application of pihtoin ointment and traumagel preparation in the treatment of subclinical mastitis of cows contributed to the recovery of $100 \%$ of cows and caused a decrease in the number of mesophilic aerobic and optional anaerobic microorganisms in milk 2.6 times and amounted to 180 thousand $\mathrm{CFU} / \mathrm{cm}^{3}$.

The number of somatic cells in the milk of cows decreased 1.3 times and amounted to 320 thousand in $1 \mathrm{~cm}^{3}$.

The combined use of pihtoin ointment and the trauma-gel preparation with subclinical mastitis of cows reduced the cost of treatment 3.8 times.

Drugs on a plant basis have excluded the damage from milk rejection, which is present in the treatment with antibiotics.

We recommend the combined use of herbal preparations pihtoin ointment and gel trauma 2 times a day with an interval of 12 hours for 5 days in the treatment of subclinical mastitis of cows during the lactation period.

\section{References}

[1] N.U. Basova "The effectiveness of the Heavy Duty Udder Stabilizer drug in the prevention of mastitis in cows", Russian Journal. Problems of veterinary sanitation, hygiene and ecology, 2015, No. 4 (16), p. 60 62 .

[2] A.V. Vostroilov, L.G. Khromova "Productive longevity of cows of the red-and-white breed", Bulletin of the Voronezh State Agrarian University, 2009, No.1, p. 47-53.

[3] A.V. Vostroilov "Ways to improve the Simmental breed of cattle", Vestnik VGAU, 2011, No.1, p. 64-66.

[4] A.V. Vostroilov, K.A. Lobodin "Reproductive ability of red-and-white cows of the Voronezh type", Zootechnics, 2012, No.9, p. 30-31.

[5] N.T. Klimov, Ya.S. Klyuchnikov. "Environmentally safe methods of treatment of subclinical mastitis in cows", Problems of Veterinary Sanitation, Hygiene and Ecology, 2012, No. 1 (7), pp. 23-26.

[6] A.F. Kolchina, A.S. Barkova, M.I. Barashkin. "Modern methods in the diagnosis of pathology of the mammary gland of high-producing cows", Agrarian Bulletin of the Urals. 2012, No.12, P. 12-14.

[7] V.U. Komarov, B.L. Belkin "Sanitary treatment of cows udders - an important part in the fight against mastitis", Russian Journal. Problems of veterinary sanitation, hygiene and ecology, 2016, No.3 (19), 75-79.

[8] G.A. Larionov, L.M. Vyazova, O.N. Dmitrieva. "Damage to the udder of cows with subclinical mastitis", Russian Journal. Problems of veterinary sanitation, hygiene and ecology, 2015, No.2 (14), pp. 62-67.

[9] A.E. Makushev, G.A. Larionov, O.N. Dmitrieva "The impact of mastitis prophylaxis on the reduction of microbial contamination and increase the economic efficiency of milk production", Agrarian Bulletin of the Urals, 2016, No.09(151), pp. 26-31.

[10] G.V. Rodionov, S.L. Belopuhov, R.T. Mannapova, O.G. Dryahlih "Regulation of the number of microorganisms in raw milk", News of the Timiryazev Agricultural Academy, 2013, No.1, p. 111-119.

[11] N.A. Shurduba "The species composition of the microflora of raw milk in farms, cows affected by mastitis" Russian Journal, Problems of veterinary sanitation, hygiene and ecology, 2014, No.1 (11), p. 65-68

[12] N.A. Shurduba, V.M. Sotnikova, I.S. Osipova "Formation of enterotoxins by coagulase-negative staphylococci isolated from milk and udder secretion of lactating cows", Russian Journal. Problems of veterinary sanitation, hygiene and ecology, 2013, No.2 (10), pp. 56-58.

[13] E.S. Yatrusheva "The effectiveness of the use of products based on probiotic bacteria in the prevention of mastitis and improving the quality of milk of cows", Agrarian Bulletin of the Urals, 2017, No.2 (156), pp. $72-76$.

[14] L. Des Côteaux, J. Colloton, G. Gnemmi "Practical Atlasof Ruminantand Camelid Reproductive Ultrasonography Wiley Blackwell”, 2010, P. 228.

[15] D. Reinemann, G. Mein, D. Brav. "Troubleshooting high bacteria countsin farm milk", J. Microbiol, 2000, No23, pp. 65-79.

[16] I.R. Fasulkov "Ultrasonography of the mammary gland in ruminants: a review", Bulgarian Journal of Veterinary Medicine, 2012, No1, pp. 1-12.

[17] S. Franz, M. Floek, M. Hofmann-Parisot "Ultrasonography of the bovine udder and teat", Vet. clin. north am. food anim. Pract, 2009, Vol. 25, pp. 669-685. 